\title{
PENINGKATAN KETERAMPILAN BERBICARA MENGGUNAKAN MODEL SHOW AND TELL MELALUI PEMBELAJARAN DARING DENGAN PLATFORM WHATSAPP VIDEO CALL
}

\author{
Niswatun Ngafifah \\ PPG Prajabatan PGSD Universitas Negeri Yogyakarta, Yogyakarya, Indonesia \\ niswatunngafifah@gmail.com
}

Received: July $07^{\text {th }}, 2021$

Revised: July $27^{\text {th }}, 2021$

Accepted: July $29^{\text {th }}, 2021$

\section{ABSTRACT}

This study aims to improve the speaking skills of fifth-grade students of SD Negeri 1 Kalijoyo for the academic year 2020/2021 by using the Show and Tell model with the whatsapp video call platform. This research is a Classroom Action Research (CAR) which refers to Kurt Lewin (Arikunto, 2015: 42) which consists of four stages of planning, action, observation, and reflection. The research was carried out in two cycles where each cycle was carried out in four meetings. The research subjects were 16 fifth-grade students of SD Negeri 1 Kalijoyo. The techniques accumulation of data is observation, interview, document analyzing, and test. The analysis of data use triangulation technique, triangulation sources, and content validation. This TECHNIQUE research is the interactive analysis model of Miles and Huberman (Sugiyono, 2015: 337) The results of the research data in the first cycle showed that the classical completeness in the pronunciation aspect was $56.20 \%$, the vocabulary aspect was $62.50 \%$, the fluency aspect was $50 \%$, and the accuracy aspect of the story content was $56.20 \%$. Pronunciation is $93.75 \%$, vocabulary aspect is $81.25 \%$, fluency aspect is $87.50 \%$, and story content accuracy is $93.75 \%$. These data indicate that the application of the model Show and Tell with the whatsapp video call platform can improve students' speaking skills.

Keywords: elementary school; speaking skills; show and tell

\section{PENDAHULUAN}

Berbicara merupakan suatu keterampilan yang cukup kompleks, sehingga tidak serta merta keterampilan berbicara dapat diperoleh dengan mudah tanpa adanya latihan secara teratur dan cermat sejak di sekolah dasar. Keterampilan berbicara merupakan suatu hal yang esensial dalam perkembangan bahasa manusia. Tarigan (2008, p.16) dalam Shubyani (2017, p.23) mengemukakan tujuan utama dari berbicara yakni untuk berkomunikasi. Agar dapat menyampaikan pikiran secara efektif, ada baiknya sang pembicara memahami makna sesuatu yang ingin dikomunikasikan sehingga akan mencapai target 
komunikasi yang efektif. Berdasarkan kurikulum 2013 di sekolah dasar, semester 2 terdapat kompetensi dasar $(\mathrm{kd})$ keterampilan berbicara yang dituliskan pada $\mathrm{kd}$ 4.

Selain itu, keterampilan berbicara juga merupakan salah satu dari keterampilan abad 21 yang terdiri dari communication (komunikasi), collaboration (kolaborasi), creativity (kreativitas), dan critical thingking (berpikir kritis) (lihat Lely, Putra, \& Syahrilfuddin, 2020). Namun pada kenyataannya, hasil pengamatan terhadap tugas keterampilan berbicara peserta didik kelas V SDN Kalijoyo 1 belum menunjukkan hasil yang memuaskan. Peserta didik kelas $\mathrm{V}$ sudah memahami apa yang hendak mereka sampaikan tetapi belum dapat mengungkapkannya dalam bentuk kalimat dan bahasa yang baik dan benar. Rendahnya keterampilan berbicara peserta didik juga dapat diketahui dari hasil nilai PAS (Penilaian Akhir Sekolah) keterampilan berbicara diketahui bahwa peserta didik yang melebihi nilai KKM (71) sebesar 37,5\% yaitu sebanyak 6 peserta didik dari total 16 peserta didik.

Show and tell merupakan kegiatan menunjukkan sesuatu kepada audiens dan audiens menjelaskan atau mendeskripsikan sesuatu tersebut (Musfiroh, 2011, p.131 dalam Jurnal Kependidikan: Penelitian Inovasi Pembelajaran vol. 41 no. 2). Kegiatan show and tell dapat mempermudah peserta dalam mengungkapkan ide, gagasan, dan perasaan terkait media yang dilihatnya. Ketika guru menunjukkan media atau benda ketika bercerita, maka akan membantu peserta didik untuk memunculkan memori terkait media tersebut sehingga lebih mudah mengungkapkan pendapat terkait media tersebut (Musfiroh, 2011, p.132). Model show and tell cocok digunakan dalam pembelajaran untuk meningkatkan motivasi belajar peserta didik terutama dalam berbicara menyampaikan ungkapan, karena kegiatan yang dilakukan disertai dengan penggunaan media yang menarik. Model show and tell merupakan salah satu pembelajaran inovatif yang berpusat pada peserta didik agar tidak mudah bosan dalam kegiatan pembelajaran. Berdasarkan permasalahan yang dijumpai pada pembelajaran yang selama ini diterapkan di kelas V SDN Kalijoyo 1. Model show and tell diharapkan dapat meningkatkan keterampilan peserta didik terutama keterampilan berbicara sebagai bekal komunikasi dalam kehidupan sehari-hari. 
Berdasarkan pada data penelitian, maka tujuan dari penelitian ini yaitu untuk meningkatkan keterampilan berbicara pada peserta didik kelas V SD Negeri 1 kalijoyo tahun ajaran 2020/2021 menggunakan model Show and Tell melalui pembelajaran daring dengan platform whatsapp video call pada proses pembelajaran. Penelitian ini dapat dijadikan relevansi untuk mengembangkan model Show and Tell ke dalam keterampilan berbicara yang lain atau bahkan dikembangkan pada jangkauan yang lebih luas.

\section{METODE PENELITIAN}

Penelitian ini dilakukan pada kelas $V$ SD Negeri 1 Kalijoyo tahun ajaran 2020/2021 yang beralamat di desa Kalijaya, kecamatan Alian, kabupaten Kebumen. Waktu penelitian dilaksanakan dari bulan Januari 2021 sampai Mei 2021. Subjek penelitian adalah peserta didik kelas V SD Negeri 1 Kalijoyo dengan jumlah 16 peserta didik dengan 9 peserta didik laki-laki dan 7 peserta didik perempuan.

PTK ini dilakukan selama dua siklus dengan setiap siklus terdiri dari empat pertemuan (lihat Komara, Putra, \& Hermita, 2020). Setiap siklus terdiri dari empat tahapan, yaitu perencanaan, pelaksanaan, pengamatan, dan refleksi. Penelitian ini menggunakan teknik pengumpulan data observasi, wawancara, analisis data, dan tes. Sementara untuk validitas data menggunakan triangulasi teknik dan sumber. Teknik analisis data yang digunakan adalah model analisis interaktif Miles dan Huberman (Sugiyono, 2015, p.337).

Penelitian berhasil jika $80 \%$ peserta didik mendapatkan kategori terampil pada setiap aspek. Berikut adalah tabel pengelompokan peserta didik yang merupakan modifikasi dari Arikunto, Suhardjono, \& Supardi, Penelitian Tindakan Kelas (2016, p.90):

Tabel 1. Pedoman Kategori Penilaian Keterampilan Menulis Teks Eksposisi

\begin{tabular}{|c|c|}
\hline Interval Skor & Kategori \\
\hline 4,0 & Sangat terampil \\
\hline $3,0-3,9$ & Terampil \\
\hline $2,0-2,9$ & Kurang Terampil \\
\hline
\end{tabular}




\begin{tabular}{|c|c|}
\hline $1,0-1,9$ & Tidak Terampil \\
\hline $0-0,9$ & Sangat Tidak Terampil \\
\hline
\end{tabular}

\section{HASIL DAN PEMBAHASAN}

\section{Hasil Penelitian}

Hasil dan pembahasan dibagi menjadi dua penyajian data keterampilan berbicara yaitu siklus I dan siklus II. Rinciannya dapat dilihat persiklus pada penjelasan di bawah:

\section{I.I Keterampilan Berbicara siklus 1}

Hasil keterampilan berbicara siklus 1 dapat dilihat pada tabel 2.

Table 2. Distribusi Frekuensi Nilai Keterampilan Berbicara Siklus I

\begin{tabular}{|c|c|c|c|c|c|c|c|c|}
\hline \multirow{2}{*}{ Aspek } & \multicolumn{5}{|c|}{ Skor Interval } & \multirow{2}{*}{ Rerata } & \multirow{2}{*}{ Kategori } & \multirow{2}{*}{ Persentase } \\
\hline & $1,7-2,2$ & $2,2-2,9$ & $2,9-3,4$ & $3,4-3,8$ & $3,8-4,3$ & & & \\
\hline Lafal & 2 & 5 & 9 & 0 & 0 & 2,77 & $\begin{array}{l}\text { Kurang } \\
\text { terampil }\end{array}$ & $56,20 \%$ \\
\hline Kosakata & 2 & 4 & 7 & 3 & 0 & 2,70 & $\begin{array}{c}\text { Kurang } \\
\text { terampil }\end{array}$ & $62,50 \%$ \\
\hline Kelancaran & 2 & 6 & 7 & 1 & 0 & 2,59 & $\begin{array}{l}\text { Kurang } \\
\text { Terampil }\end{array}$ & $50 \%$ \\
\hline $\begin{array}{l}\text { Ketepatan } \\
\text { Isi Cerita }\end{array}$ & 0 & 7 & 6 & 3 & 0 & 2,68 & $\begin{array}{c}\text { Kurang } \\
\text { terampil }\end{array}$ & $56,20 \%$ \\
\hline
\end{tabular}

Pada siklus I setiap aspek belum mencapai indikator kinerja penelitian. Hal ini disebabkan peserta didik masih menyesuaikan perubahan pola pembelajaran dari hanya mengerjakan tugas menjadi pembelajaran menggunakan video call yang ditekankan pada keterampilan berbicara. Pada setiap aspek meskipun belum memenuhi indikator kinerja, tetapi rerata setiap aspek sudah hampir mencapai kategori terampil. Maka dari itu penelitian dilanjutkan ke dalam siklus 2 dengan menyelesaikan kendala pada proses pembelajaran berdasarkan hasil reflesi siklus 1. 


\subsection{Keterampilan menulis keterampilan berbicara siklus II}

Hasil keterampilan menulis teks eksposisi siklus 2 dapat dilihat tabel 4.

Table 3. Distribusi Frekuensi Nilai Keterampilan Berbicara Siklus II

\begin{tabular}{|c|c|c|c|c|c|c|c|c|}
\hline \multirow{2}{*}{ Aspek } & \multicolumn{5}{|c|}{ Skor Interval } & \multirow{2}{*}{ Rerata } & \multirow{2}{*}{ Kategori } & \multirow{2}{*}{ Persentase } \\
\cline { 2 - 8 } & $\mathbf{1 , 7 - 2 , 2}$ & $\mathbf{2 , 2 - 2 , 9}$ & $\mathbf{2 , 9 - 3 , 4}$ & $\mathbf{3 , 4 - 3 , 8}$ & $\mathbf{3 , 8 - 4 , 3}$ & & & \\
\hline Lafal & 0 & 1 & 5 & 4 & 6 & 3,3 & Terampil & $93,75 \%$ \\
\hline Kosakata & 2 & 4 & 7 & 3 & 0 & 3,2 & Terampil & $81,25 \%$ \\
\hline Kelancaran & 2 & 6 & 7 & 1 & 0 & 3,4 & Terampil & $87,50 \%$ \\
\hline $\begin{array}{c}\text { Ketepatan Isi } \\
\text { Cerita }\end{array}$ & 0 & 7 & 6 & 3 & 0 & 3,6 & Terampil & $93,75 \%$ \\
\hline
\end{tabular}

Pada siklus II, telah terjadi peningkatan dari segala aspek dibandingkan dengan siklus I. Peningkatan hasil tersebut juga memenuhi indikator kinerja penelitian dengan hasil $80 \%$ perserta didik mendapatkan kategori terampi dalam setiap aspek. Meskipun begitu, pada aspek kosakata mendapatkan rerata skor terendah. Hal ini disebabkan bahasa daerah peserta didik digunakan dalam kegiatan sehari-hari sehingga terkadang terucap secara tidak sengaja saat sedang mempresentasikan, menceritakan, atau mengiklankan produk dalam penilaian keterampilan berbicara peserta didik.

\section{Pembahasan Peneltian}

Ketercapaian indikator kinerja dalam penelitian ini yaitu jika $80 \%$ peserta didik memperoleh kategori terampil dalam setiap aspek. Setiap aspek terdiri atas empat deskriptor yang masing-masing memiliki skor satu. Aspek yang dinilai terdapat empat aspek yaitu aspek lafal, aspek kosakata, aspek kelancaran, dan aspek ketepatan isi cerita. Pada setiap aspek peserta didik akan mendapatkan kategori terampil jika memenuhi paling sedikit tiga deskriptor dalam satu aspek. Berdasarkan data siklus I dan siklus II terjadi peningkatan pada aspek lafal dari $56,20 \%$ menjadi $93,75 \%$, pada aspek kosakata dari $62,50 \%$ menjadi $81,25 \%$, pada aspek kelancaran dari $50 \%$ menjadi $87,50 \%$, dan pada aspek ketepatan isi cerita dari $56,20 \%$ menjadi $93,75 \%$.

Maka, dapat disimpulkan bahwa terjadi peningkatan keterampilan menulis peserta didik secara keseluruhan maupun pada setiap aspek sudah mencapai indikator kinerja penelitian sehingga penelitian telah berhasil. Hal ini menunjukkan 
bahwa peningkatan terus terjadi. Meskipun begitu ada beberapa permasalahan yang ditemui pada siklus 1. Permasalahan tersebut yaitu peserta didik terkadang menyisipkan bahasa daerah, menggunakan bahasa Indonesia yang tidak baku, pengucapan kata yang kurang jelas, dan masih tersendat atau berhenti di tengahtengah saat bercerita atau melakukan presentasi. Namun, hal tersebut sudah dapat diatas dengan baik pada siklus II contohnya dengan menggunakan media yang berbeda seperti lingkungan atau benda-benda disekitar peserta didik. Penggunaan tema yang melekat pada kehidupan peserta didik juga menjadi salah satu kunci keberhasilan karena peserta didik lebih mengerti apa yang akan mereka utarakan. Hal ini sejalan dengan penelitian yang dilakukan oleh Hidayat (2021, p.4) bahwa pembelajaran menggunakan dunia nyata peserta didik dan media yang beragam meningkatkan pemahaman peserta didik dalam mempelajari suatu materi.

\section{SIMPULAN}

Implementasi model Show and Tell pada keterampilan berbicara terdiri dari dua tahap., yaitu tahap show dan tahap tell. Show yang berarti menunjukkan media bisa berupa gambar, video, benda nyata, maupun lingkungan sekitar. Sedangkan tahap tell, peserta didik menceritakan atau mempresentasikan sesuatu. Hasil penerapan model Show and Tell pada keterampilan berbicara pada peserta didik SD Negeri 1 Kalijoyo tahun ajaran 2020/2021 telah terjadi peningkatan. Ketercapaian aspek lafal meningkat dari 56,2\% menjadi 93,65\%, aspek kosakata dari $62,50 \%$ menjadi $81,25 \%$, aspek kelancaran dari $50 \%$ menjadi 87, dan aspek ketepatan isi cerita dari $56,20 \%$ menjadi $93,75 \%$. Penelitian telah berhasil dengan tercapainya indikator kinerja penelitian pada siklus II dengan kendala signifikan yaitu peserta didik terkadang menyisipkan bahasa daerah, menggunakan bahasa Indonesia yang tidak baku, pengucapan kata yang kurang jelas, dan masih tersendat atau berhenti di tengah-tengah saat bercerita atau melakukan presentasl sudah dapat teratasi 


\section{DAFTAR PUSTAKA}

Arikunto, S., Suhardjono, \& Supardi. (2016). Penelitian Tindakan Kelas. Jakarta: Bumi Aksara

Arikunto, S. (2006). Prosedur Penelitian Suatu Tindakan Praktik. Jakarta: Rineka Cipta.

Arviani, I., \& Fajriyah, K. (2018). Keefektifan Model Show and Tell untuk Meningkatkan Keterampilan Berkomunikasi pada Materi Proklamasi Kemerdekaan Siswa Kelas V SD Negeri Babalan. Al Ibtida: Jurnal Pendidikan Guru MI, 5(1), 1-10. https://syekhnurjati.ac.id/jurnal/index.php/ibtida/article/view/1877

Hidayat, D. A., Artika, A., \& Sugandi, A. I. (2021). Penerapan Pendekatan Realistik Matematis untuk Meningkatkan Hasil Belajar Himpunan Siswa Kelas VII SMP PGRI Arjasari. Tunjuk Ajar: Jurnal Penelitian IImu Pendidikan, 4(1), 1-15. https://ita.ejournal.unri.ac.id/index.php/JTA/article/view/7877/pdf 1

Komara, F. H. T., Putra, Z. H., \& Hermita, N. (2020). Penerapan model pembelajaran kooperatif tipe picture and picture untuk meningkatkan hasil belajar matematika siswa kelas IVB SDN 136 Pekanbaru. Tunjuk Ajar: Jurnal Penelitian IImu Pendidikan, 3(2), 146 - 162. http://dx.doi.org/10.31258/jta.v3i2.146-162

Lely, M., Putra, Z. H., \& Syahrilfuddin. (2020). Fifth grade students' creative thinking in solving open-ended mathematical problems. Journal of Teaching and Learning in Elementary Education, 3(1), 58-68. http://dx.doi.org/10.33578/jtlee.v3i1.7829

Musfiroh, T. (2011). Show and Tell Edukatif Untuk Pengembangan Empati, Afiliasi- resolusi Konflik, Dan Kebiasaan Positif. Jurnal Kependidikan: Penelitian Inovasi Pembelajaran, https://journal.uny.ac.id/index.php/jk/article/view/2219/1831

Subhayni, dkk. (2017). Keterampilan Berbicara. Aceh: Syah Kuala University Press.

Sugiyono. (2015). Metode Penelitian Pendidikan. Bandung: Alfabeta.

Sugiyono. (2015). Metode Penelitian (Pendekatan Kuantitatif, Kualitatif, dan $R \& D)$. Bandung: Alfabeta. 